Volume 4 Issue 1, March 2019: pp. 1-10. Copyright @ LamLaj. Faculty of Law, Lambung Mangkurat University, Banjarmasin, South Kalimantan, Indonesia. ISSN: 2502-3136 | e-ISSN: 2502-3128.

Open Access at: http://lamlaj.ulm.ac.id/web/

\title{
HUMAN RIGHTS AND LAW ENFORCEMENT
}

\section{Fransiska Novita Eleanora ${ }^{1}$, Andang Sari ${ }^{2}$}

Faculty of Law, Bhayangkara University.

Jl. Darmawangsa Raya 1, Pulo, Kebayoran Baru, South Jakarta, Jakarta 12140 Indonesia Fax: (021)7231948+E-mail: vita_eleanor@yahoo.com

Faculty of Law, Bhayangkara University.

Jl. Darmawangsa Raya 1, Pulo, Kebayoran Baru, South Jakarta, Jakarta12140 Indonesia Fax: (021)7231948+E-mail:Andangsari29@yahoo.co.id

Submitted : 19/12/2018 Reviewed 23/03/2019 Accepted:31/03/2019

\begin{abstract}
Humans born into the world have declared their rights and natural rights as gifts from the Almighty, God and every State must recognize them as legal subjects who must always be respected and protected to realize human values well. Therefore; no one can or can act negatively, including the state or even the authorities or the government. Conceptually, a country that is expected to realize it is only a legal state that is considered legitimate and adheres to the notion of democracy, namely democracy will become a rule and law. The realization of the rule of law is to take action against perpetrators who are proven to have committed crimes and human rights violations. This paper explains that there are still many cases of gross violations of human rights that have not been clearly revealed and the perpetrators have not been given appropriate punishment, by giving sanctions to the perpetrators, so that law enforcement is not realized. The embodiment of the rule of law is that it can capture cases of gross violators of human rights and convict the perpetrators in accordance with the laws that apply in accordance with the characteristics of the rule of law. The problem is whether law enforcement has been realized especially in human rights violations and can be resolved through negotiation, conciliation and mediation.
\end{abstract}

Keywords: human rights; law enforcement; law

\section{INTRODUCTION}

The attachment of human rights is what is called humanity and its principle and the right of their existence. Without those rights, humans cannot live properly as humans. The community obtains these rights or obtains its presence in human occupation since birth and is in the community or in the midst of its life. Human rights are hereinafter abbreviated as human rights and indeed are very general or also universal and because or it is believed 
that there are some or some of the existing or inherent rights that are owned or not, or without various differences, are considered fundamental. The notion that human rights is called also very supra-legal, which contains meaning or meaning does not only depend on the provisions of a place or country even/or rules or a constitution, or government power, because everything is assumed to be derived from God as a source that is indeed higher. ${ }^{1}$

The recognition of the existence of human rights is carried out by the State by giving appropriate punishment to the perpetrators and this is also a form of law enforcement. Because Indonesia is a rule of law where the aim is to realize a just and prosperous society, if human rights violations occur, injustice then the State is considered a failure to prosper the community or its citizens. This means that if violations or crimes against human rights occur, the perpetrators must be truly arrested, detained and tried according to the applicable law based on evidence and evidence available.

As a rule of law that is inseparable from the principle of rule of law, which views everyone as having equality before the law. there are a number of crimes, namely crime of genocide and serious crime of ham. the two crimes clearly included extraordinary crimes and the perpetrators were tolerated again, meaning that the perpetrators had to be threatened with severe punishment because they could already be considered as murderers who had

1 Bazar Harahap dan Nawangsih Sutardi. 2006. Hak Asasi Manusia Dan Hukumnya, Jakarta: PECIRINDO, hlm.3 lost the lives of others or lost the right to life. ${ }^{2}$

The realization of law enforcement can be done by revealing cases that occur in the community, because in principle, as a legal state there is no discrimination, there is no difference, all people are equal before the law, meaning those who are guilty must be asserted firmly, thus creating a just society and prosperous, and the law is considered to have authority.

In enforcing it must reflect world peace and aimed at goals that provide the ability for protection and in principle carried out by negotiation or precisely deliberation without the need to feel there is fear or anxiety in enforcing it. Then entered the Renaissance period or the era and the revival of the darkness that was mid-century with the emergence of great thinkers from Europe such as Karl von Savigny, a follower of the history school (law grows and develops together in society, meaning that law is not made). De La Montesquieu (in his lecture the existence of Trias Politica (executive, legislative and judicial) John Locke, adherent to the flow of natural law, said that before the existence and formation of the State, human nature was bound to the law, having the right to life, the right to freedom and freedom the right and the right to own everything. Rights that are very servant cannot be taken or revoked by anyone, and Immanuel Kant, explains that the State must guarantee its citizens to have freedom in the legal environment, bound by the provisions of the law exist and follow the will of the peo-

2 Koesparmono Irsan. 2009. Hukum Dan Hak Asasi Manusia. Jakarta: Yayasan Brata Bakti, hlm. 12-15 
ple. ${ }^{3}$

Starting from the nineteenth century and continuing in the twentieth century, and entering the present century, ideas, ideas, and thought concepts from these great figures have begun to be read and made as normative laws about human values as the most fundamental and fundamental. In the universal perception, there is also the meaning that the same as almost all countries, namely the right to torture, means that it can be said that every person or whoever they are may not be tortured or treated inhumanly.

Regarding this human rights, the United Nations has produced several important certificates, including the 1948 humans and Declarations of their basic and universal rights in 1948 (Declaration of Human Rights), in 1966 The International Convention on Civil and Politics is a right to be signed, the International Convention on Economic Rights and Social as well as culture. The 1993 Vienna Declaration resulted in the achievement of a consensus between Western countries and non-Western countries about the universalism of Human Rights, each member country of the United Nations has characteristics based on existing conditions ${ }^{4}$

Then the Vienna Declaration and Program of Action was born in Vienna, in 1993. Then in 2002 the International Criminal

3 Andrea Sangiovanni.2016 “Are Moral Rights Necessary for the Justification of International Legal Human Rights?” Ethics \& International Affair. 30 (4): 475

4 Nurul Qamar. 2013. Hak Asasi Manusia Dalam Negara Hukum Demokrasi, Jakarta: Sinar Grafika., hlm. 17-21
Court was established, whose authority tried cases of humans and violations of their rights and principles such as crimes against humanity, genocide, and war crimes. Genocide is a crime from acts of religious, racial, ethnic, and national groups, which intend to destroy, and destroy actions are carried out in various forms that kill group members, which are severe physical and/or mental that can be caused by suffering to group members resulting in destruction physically, whether in whole or in part, impose measures aimed at preventing birth in the group. ${ }^{5}$

For developed countries, as well as newly developing countries, including relatively new countries from colonialism apart from the shackles of colonialism such as Indonesia like the other newly independent countries, these countries are members of the United Nations membership must enact UN conventions (agreements between countries) on human rights, taking into account the universality and domesticity of their values for each country.

For this reason, Indonesia has enacted the on Human Rights of Convention regarding other cruel Punishment, treatment and torture must be addressed or human beings and their dignity demeaned (Law No. 5 of 1998), this is a step that attracts attention so that humans become aware that human rights are inherent human beings which must be respected by every human being, because the gift given by God is human rights, and this is said by humanists and defenders that without a philo-

5 Brian Kin Ho. 2016."Public Rights, Private Wrongs", Res Publica, 22(4):482 
sophical and strong concept among them, and politics from the approach and lack of resources and resources which is really needed for and determines the various presence of content from humans and their human rights which are considered substantive.

Human rights have become a global problem today in addition to the problems of democracy and environmental problems, where this is a very serious problem, especially for countries that obey, respect and protect them as human beings having the rights and principles of citizens without discrimination. In the definition of human rights there is a meaning of protection from someone from oppression by anyone. In recent years human and human rights problems have developed rapidly, especially in the late 20th century and at the beginning of the 21 st century, both nationally and internationally. So that human rights have become one of the main topics discussed long ago throughout the world. Especially since the publication of the Universal Declaration of Human Rights and Human Rights in 1948, each member country must uphold humanity and human rights to be promoted. Almost every country in the world violates human rights, both gross violations and minor violations. This can occur due to certain factors, such as conditions and opportunities that are also possible because the country's legal instruments are inadequate or not affordable. Therefore, in human protection and their human rights are given protection, there must be and be treated as a set of instruments as a legal basis. The protection provided is by limiting existing legal rules, giving sanctions to perpetrators and violators of severe human rights, law enforcement must be done and not selective from one another. There are still many cases of gross violations of human rights which until now have not yet been revealed and handed down by the criminal to the perpetrators, while the victims on the one hand have found justice in front of the law. ${ }^{6}$

\section{METHODS}

The research method used in this paper is a research with normative juridical methods, namely methods of research principles and theories. The data form of the a secondary material obtained from literature (tracing library materials). Research normative The analysis can use logically and normatively based on legislation and logic on legal principles is carried out on written and unwritten positive law to assess concrete decision making. Because the objective of using the juridical normative of this paper is the norm. The definition of rules includes the principle of law, rules in the strict sense (values), concrete legal regulations. Research has a normative law in form of the legal principles and legal systems.

\section{ANALYSIS AND DISCUSSION Human and Human Rights Affiliation in the Law State \\ In all human life, the law can break through both the most principle, simple things, and in the deepest and most funda- \\ 6 Binsar Gultom. 2010. Pelanggaran HAM Dalam Hukum Keadaan Darurat Di Indonesia, Jakarta: PT. Gramedia Pustaka Utama, hlm. 27-32}


mental things. Indonesia, which already has the basis and life view of Pancasila which is full of values of justice for human beings and human rights, but has not been applied in its entirety and perfectly. So that the effort to understand the values of Pancasila in the Indonesian state of law has not yet arrived. Therefore, the implementation of the Pancasila principle in community life has not been possible because there has not been a single unity of meaning about Pancasila.

Because the government has an advantage of one level above its citizens, with its duties, among others, to guarantee the creation of law and justice in society, then with a view of the Pancasila life. It is reasonable to propose how the implementation of one of and justice human reflection and the implementation of its human rights are always aimed at the government. The legal basis that must regulate humans and the existence of their human rights must be maintained by the government itself, therefore human rights at the stage of implementation are included in legal matters and must be regulated through law.

The development of ideals must be adapted to an existing talent that is the basis and the basis for the opportunity and something absolute development of rights will be its principle. Thoroughly is a human nature and very basic of rights and principles because it is believed that all types and genitals, nations or races should not be seen as such and are supra and legal, which means the state, or the power of government and laws and government and power, even rights human beings can stand alone because the highest source is God.
Obligations carried out together with their responsibilities from individuals, countries, communities and even the government to always uphold and humans and their rights must be respected and protected all without exception. The nature of each human being and its human rights as a combination and responsibility between human beings and their rights will always be balanced and synergistic, where if all three of the elements are inherent in the lives of every human or individual, chaos, arbitrariness and even anarchism will arise. Having the same dignity and degree is the property of every human being in this world, as well as having the same obligations or rights always trying to protect their human rights from acts of violation by other humans that harm their original rights.

Recognition of the real struggle has been recorded in history as outlined in the charter of an award as a monument to human rights from the government, such as the Magna Charta in 1215, the Bill of Rights in 1689, the Declaration des Droits in 1789, and the Human Rigts of Declaration. There have been many violation of the rights and principles of all humans in Indonesia, for example gross human violations and their rights, namely their rights in Aceh existing form inside property seizure, kidnapping and murder during the conflict between GAM and TNI, the Tanjung Priok incident on 12 September 1984, the New Order government should it imposes a civil emergency, but it is not implemented. ${ }^{7}$

7 R. Wiyono. 2015. Pengadilan Hak Asasi Manusia Di Indonesia. Edisi Kedua Jakarta: Prenada Media Group, hlm. 16 
Thus, actions that need to be taken immediately the saving of every human life humanity and victims of property at that time must be dealt with in such a way, even if they have violated laws which at that time were normal. If such a violation evidently the only way out to overcome the situation, it can be justified because of the reasons for the civil emergency, but must be declared in advance to the public by the President.

\section{Violations of Humans and their rights Ap- plicable Laws}

The world and all have given the Regulations for the basis of its existence humanity and human rights which have been recognized by the Magna Charta in 1215, the Bill of Rights in 1689, and the Declaration of $\mathrm{Hu}-$ man Rights. Determination and guidelines have been established in the union of nations which are concerning humanity and its cause or referred to as the Declaration. Women and children regarding the abolition and discrimination against them have also been regulated in the Union of nations in the convention, and various other international instruments governing human rights.

Furthermore, in the regulation of human rights, humans have the right to get a life, and or cannot get coercion, the right to personal freedom, the right to personal freedom, the mind, to get religion and conscience and heart, enslaved is not a right

That the state and law give the right to someone to resolve all violations of their principles of the form rights through international and forum and nationally through the law and its efforts. $^{8}$

Then related to the people and their rights and rights of the form violations, there must be a court to prosecute human violations of the rights and principles such as genocide, namely destruction or destruction of all or a group of people, religion and group, ethnic group and race, in order to kill groups and members so that resulting in suffering of the form mental very heavy and related to the physical. The prospect of upholding human rights in the future will certainly be better and brighter, if renewal and the existence of an establishment law are carried out, it will continue to show progress that has a better meaning for the human rights struggle in recent years.

\section{Human and Rights of their Violations In- donesia And Their Resolutions And Con- straints}

The Indonesian state and the occurrence of a violation of human rights concerning its rights and principles, especially in the regions, are very suffocating to the hearts of the Indonesian people as a nation always and will continue to uphold the existence of a value and dignity and human dignity on the face of Indonesia. Events that occur during the time of rolling are still going on despite intense occurrence of ups and downs, there are times when the incidence Humans and Violations of their Rights is low and at other times it increases. ${ }^{9}$

8 Soerjono Soekanto. 2010. Faktor-Faktor Yang Mempengaruhi Penegakan Hukum. Jakarta: PT Raja Grafindo Persada, hlm. 31-34

9 Cristina Lafont. "Should We Take the "Human" Out of Human Rights? Human Dignity in a 
Indeed, in reduced let alone eliminate violation of the rights of all humans it is not an easy job but it requires performance from all elements of the Indonesian nation to and to always create harmony and an atmosphere that is very conducive without any violence that will occur for human rights enforcement. democratic, comprehensive and touching the conscience of the community itself. So that it is proper for the Indonesian people in this case the government that has the mandate of the people, which is the mandate to elevate the welfare and peace among fellow humans ${ }^{10}$.

Settlement efforts in cases rights violated from humans need a means of settlement that is used in resolving even in resolving an event or case involving human rights and its violations are expected to certainly prioritize applicable legal norms in resolving issues rights violated from humans through consultation, negotiation, mediation, conciliation and expert judgment.

Regardless of who begins to make a situation that is not harmonious in the community affected by human rights violations, it must be realized that the means of resolution by means of violence or with weapons are certainly not effective in resolving any problems that occur. This means that the means of settlement that all parties can accept so with community layer is a solution that prioritizes human values by using a more humane method, namely

Corporate World" Ethics \& International Affairs, 30(2):236

10 Bagir Manan. 2017. Perkembangan Pemikiran Dan Pengaturan Hak Asasi Manusia Di Indonesia. Bandung: Alumni, hlm. 42-45 by mediating peaceful dialogue between the parties in conflict.

\section{Law Enforcement}

Said as law enforcement means how the law made by the ruler is enforced, especially in crime and human rights violations which until now the cases have not been revealed in the community. In fact, to uphold the rule of law or legal reform, everyone has the right to demand justice. Enforcing the law is not limited to giving severe punishment to the perpetrators but also providing compensation to the victims. the victims here are those who suffer from the crime. ${ }^{11}$ But on the other hand, to reveal cases of gross human rights violations seems very slow, even though law enforcement should not seem slow but strive for how everyone can claim their rights and seek justice. By adhering to the rule of law principle, the existence of a free and impartial judiciary and no discrimination, the same position as people in law and government. in other words, the state has the full right to bring the perpetrators to trial if they are found guilty of crimes and violations of human rights.

\section{CONCLUSION}

The realization of law enforcement in violating human rights by applying applicable legal norms in resolving issues of rights violated through consultation, negotiation, mediation, conciliation and expert judgment.

The rule of law principle as a form of

\footnotetext{
11 Masyhur Effendi. 1994. Dimensi Dinamika Hak Asasi Manusia Dalam Hukum Nasional Dan Internasional. Jakarta: Ghalia Indonesia., hlm. $39-41$
} 
manifestation of a democratic state, means prioritizing the public interest or the interests of its citizens as a form of providing protection and enforcement of its rights

\section{Suggestion}

The government needs to make an instrument/regulation related to human rights. So human rights violations of any kind must be processed through the court in this case the human rights court. For the sake of law enforcement that is related to human rights violations, especially concerning the resolution of gross human rights violations.

There must always be coordination and even active cooperation between the parties, the government, law enforcement officials, and the community to always report if violation of rights then occurs in their environment or around them.

\section{BIBLIOGRAFI}

Effendi, Masyhur. 1994. Dimensi Dinamika Hak Asasi Manusia Dalam Hukum Nasional Dan Internasional, Jakarta: Ghalia Indonesia.

Gultom, Binsar. 2010. Pelanggaran HAM Dalam Hukum Keadaan Darurat Di Indonesia, Jakarta : PT. Gramedia Pustaka Utama

Harahap, Bazar Dan Nawangsih Sutardi. 2006. Hak Asasi Manusia Dan Hukumnya. Jakarta: PECIRINDO.

Ho, Brian Kin. 2016. "Public Rights, Private
Wrongs", Res Publica, 22 (4):482

Irsan, Koesparmono. 2009. Hukum Dan Hak Asasi Manusia. Jakarta: Yayasan Brata Bakti

Manan, Bagir. 2017. Perkembangan Pemikiran Dan Pengaturan Hak Asasi Manusia Di Indonesia. Bandung: Alumni

Lafont, Cristina. "Should We Take the 2016. "Human" Out of Human Rights? Human Dignity in a Corporate World" Ethics \& International Affairs, (30)2: 236

Qamar, Nurul. 2013. Hak Asasi Manusia Dalam Negara Hukum Demokrasi. Jakarta: Sinar Grafika.

Sangiovanni, Andrea. 2016 "Are Moral Rights Necessary for the Justification of International Legal Human Rights?" Ethics \& International Affairs, 30(4):475

Soekanto, Soerjono. 2010. Faktor-Faktor Yang Mempengaruhi Penegakan Hukum. Jakarta: PT Raja Grafindo Persada

Wiyono, R. 2015. Pengadilan Hak Asasi Manusia Di Indonesia. Edisi Kedua. Jakarta: Prenada Media Group

\section{Legislation}

Indonesia, Undang-Undang Nomor 5 Tahun 1998 Konvensi Menentang Penyiksaan dan Perlakuan atau Penghukuman Lain yang Kejam, Tidak Manusiawi atau Merendahkan Marabat Manusia, Law, Number 5: 1998

Indonesia, Undang-Undang Nomor 39 Tahun 1999 Tentang Hak Asasi Manusia. Law, Number 39: 1999 